\title{
To International Journal of ES Occupational and Environmental Safety
}

\section{Increased urine chromium concentrations in a worker exposed to lead chromate due to medicinal herb intake}

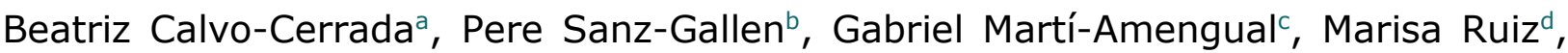 \\ Eva Maríne, Anselmo López-Guillén ${ }^{f}$ \\ accupational Medicine and Toxicology Unit, Department of Medicine, Faculty of Medicine and Health Sciences, \\ University of Barcelona, ES (beatriz.calvo.cerrada@gmail.com), boccupational Medicine and Toxicology Unit, \\ Department of Medicine, Faculty of Medicine and Health Sciences, University of Barcelona, ES (17039psg@comb.cat), \\ ORCID: 0000-0001-5592-4014, ' Occupational Medicine and Toxicology Unit, Department of Medicine, Faculty of \\ Medicine and Health Sciences, University of Barcelona, ES (gabrielmarti@ub.edu), ORCID: 0000-0002-0316-5260, \\ 'Prevengraf, Servicio de Prevención de Riesgos Laborales, Terrassa, Barcelona, ES (marisa@prevengraf.com), \\ ePrevengraf, Servicio de Prevención de Riesgos Laborales, Terrassa, Barcelona, ES (eva@prevengraf.com), \\ fOccupational Medicine and Toxicology Unit, Department of Medicine, Faculty of Medicine and Health Sciences, \\ University of Barcelona, ES (alopezguillen@gmail.com), ORCID: 0000-0002-2462-7567
}

\section{Article History}

Received August 03, 2020

Accepted April 12, 2021

Published April 30, 2021

\section{Keywords}

Hexavalent chromium

Lead chromate

Occupational medicine

Medicinal herbs

Case report

DOI:

10.24840/2184-0954_005.001_0002

ISSN:

2184-0954

Type:

Article

Oopen Access

Peer-Reviewed

(c) (i) $\mathrm{CC} \mathrm{BY}$

\begin{abstract}
Background: Hexavalent chromium compounds are sensitizers of the skin and lung. Chronic exposure to hexavalent chromium compounds is associated with respiratory effects and ulceration and perforation of the nasal septum. Such compounds are also considered carcinogens of the lung and nasal and paranasal sinus. Objectives: To demonstrate the importance of studying occupational and non-occupational exposure when assessing the concentration of substances in the urine. Case study: A study was conducted of environmental chromium concentrations in the workplace. In addition, an occupational medical examination was performed, recording activities inside and outside the workplace, eating habits, blood lead and urine chromium at the beginning and end of the workday. Results: One worker exposed to lead chromate presented high chromium concentrations in urine (up to $62 \mu \mathrm{g} / \mathrm{l}$ before the working day and $52 \mu \mathrm{g} / \mathrm{l}$ at the end of the working day). Environmental chromium concentrations in the workplace were below $0.25 \mu \mathrm{g} / \mathrm{m}^{3}$. In view of the results, a full study was conducted of the patient's habits outside work. He reported having bought a kilo of a medicinal herb infusion at a street market three weeks previously. The concentration of total chromium in the prepared infusion was $12000 \mu \mathrm{g} / \mathrm{l}$. The patient stopped consuming the medicinal herb. Subsequently, the urine chromium analysis was below $0.5 \mu \mathrm{g} / \mathrm{l}$. Discussion and Conclusions: This case is interesting because it demonstrates that the consumption of medicinal herbs can interfere with biological monitoring of workers exposed to hexavalent chromium compounds. This may give rise to confusion and can also create legal problems for companies and workers. It is important to provide advice to workers and to investigate their habits outside work, especially when there is a discrepancy between environmental and biological values. In this case, the increase in urinary chromium is due to the consumption of medicinal herbs.
\end{abstract}

\section{INTRODUCTION}

Chromium $(\mathrm{Cr})$ is a widely distributed metal on Earth, most commonly found in two forms: trivalent (III) and hexavalent (VI). The trivalent form is found in biological tissues and food, while hexavalent chromium (Cr VI) is derived from trivalent chromium (Cr III) by heating to an alkaline $\mathrm{pH}$, and it is used for industrial applications. At very low concentrations, $\mathrm{Cr}$ VI is reduced to $\mathrm{Cr}$ III by reducing substances present in the food itself and by the acidic $\mathrm{pH}$ of the stomach, which acts as a preventive barrier against absorption of Cr VI (ATSDR, 2012; Mertz, 1993). Cr III plays an essential role in insulin 
regulation, regulating the metabolism of carbohydrates, lipids, and proteins. It is the predominant form in soil and, therefore, also in food, whereas the presence of Cr VI in food and water is due to industrial pollution.

The European Food Safety Authority (EFSA) has established a tolerable daily intake of $300 \mu \mathrm{g} / \mathrm{kg}$ body weight, based on chronic toxicity studies in which no adverse effects were found at the doses studied (EFSA, 2014). In addition, it has determined total chromium in the following food groups ( $\mu \mathrm{g} / \mathrm{g}$ fresh weight): meat and derivatives $(0.87$ $\mu \mathrm{g} / \mathrm{g})$; fish and seafood $(0.78 \mu \mathrm{g} / \mathrm{g})$; vegetables $(0.16 \mu \mathrm{g} / \mathrm{g})$; tubers $(0.36 \mu \mathrm{g} / \mathrm{g})$; fruit $(0.26 \mu \mathrm{g} / \mathrm{g})$; eggs $(1.15 \mu \mathrm{g} / \mathrm{g})$; milk $(0.27 \mu \mathrm{g} / \mathrm{g})$; dairy products $(0.75 \mu \mathrm{g} / \mathrm{g})$; bread and cereals $(1.02 \mu \mathrm{g} / \mathrm{g})$; vegetables $(0.42 \mu \mathrm{g} / \mathrm{g})$; oils and fats $(1.50 \mu \mathrm{g} / \mathrm{g})$; and pastries $(1.28 \mu \mathrm{g} / \mathrm{g})$.

The concentration of chromium in water for human consumption in Barcelona is lower than $5 \mu \mathrm{g} / \mathrm{L}$, the limit of detection of the test. The estimated chromium intake of an adult male through food and water consumption is $755.2 \mu \mathrm{g} / \mathrm{day}$. The most significant contributions come from bread and cereals accounting for $237.3 \mu \mathrm{g} /$ day, meat and derivatives, accounting for $134.6 \mu \mathrm{g} /$ day (ACSA, 2017).

Hexavalent chromium compounds are widely used in industry for their anticorrosive properties, hardness and durability, and are mainly found in the chromite processing industry, electroplating, paints, pigments, welding, ferroalloys, fungicides and corrosion inhibitors (CDC, 2013; NIOSH, 2013).

Acute poisoning from ingestion of hexavalent chromium compounds can cause digestive disturbances (vomiting, diarrhoea, abdominal pain, intestinal bleeding) and acute kidney failure (Sanz et al., 1991; Barceloux, 1999). Fatal cases due to circulatory collapse have been described (Loubières et al., 1999). In addition, hexavalent chromium compounds are sensitisers of skin (Figure 1) and lung (Barceloux, 1999; Handley and Burrows, 1994).

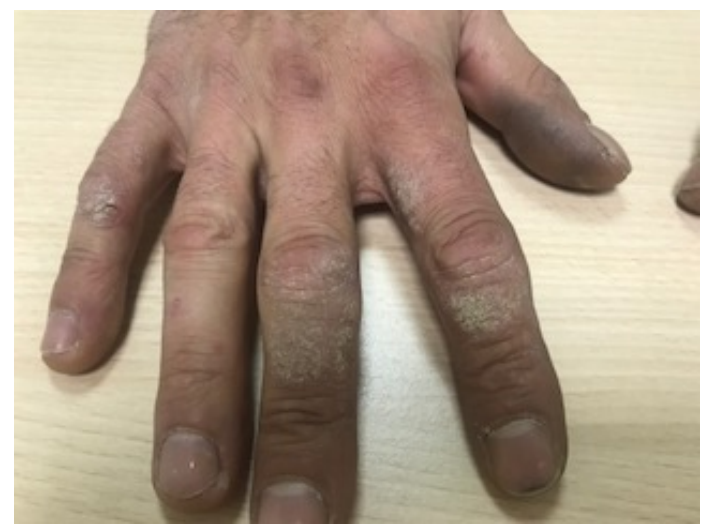

Figure 1. Hexavalent chromium allergic dermatitis

In a study of mean $\mathrm{Cr}(\mathrm{VI})$ exposure and the median time from the first day on the job to the diagnosis of several skin or membrane irritations, Gibb et al. (2000) observed dermatitis and irritated skin, ulcerated skin, burns (30\% of the cohort) and conjunctivitis. The mean $\mathrm{Cr}$ (VI) concentration (measured as CrO3) ranged from 0.049 $\mathrm{mg} / \mathrm{m}^{3}$ to $0.058 \mathrm{mg} / \mathrm{m}^{3}$ at the time of the first diagnosis of these five effects, while days on the job until the first diagnosis ranged from 110 to 221 days (median 373 to 719 days).

Chronic exposure to hexavalent chromium compounds can cause ulcerations and perforations of the nasal septum (Figure 2). For example, in a study of 2,869 shipyard welders in Korea, Lee et al. (2002) found eleven cases of nasal septum perforation with no previous history of trauma, surgery, diseases or medication use which could explain these perforations. 


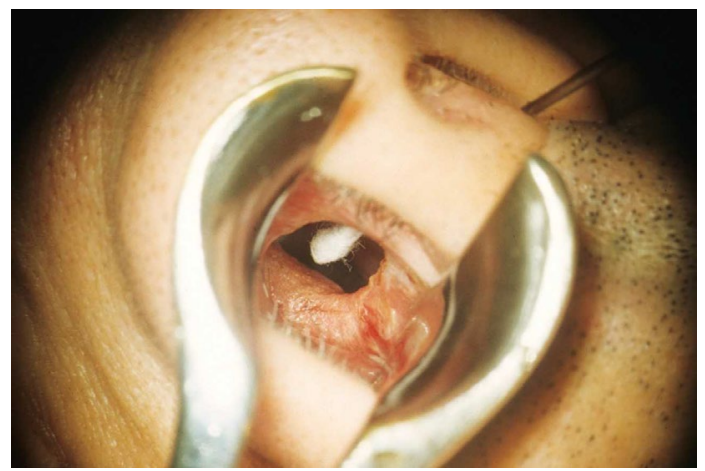

Figure 2. Perforation of the nasal septum due to occupational exposure to chromic acid

Chronic exposure can also cause respiratory disorders, which may take the form of bronchitis, pneumonia, decreased pulmonary function or pneumoconiosis (ATSDR, 2012; Barceloux, 1999; Gibb et al., 2000; Sanz et al., 1989; Sanz-Gallen et al., 1988; Sanz-Gallen et al., 1990). Furthermore, hexavalent chromium is an occupational carcinogen associated with lung cancer and sinus and nasal cancer (Figure 3A, Figure 3B). The International Agency for Research on Cancer (IARC) has concluded that there is sufficient evidence in humans to confirm the carcinogenicity of hexavalent chromium compounds as encountered in chromate production, chromate pigment production and chromium plating industries (IARC, 1990).

Several studies have linked exposure to hexavalent chromium compounds to lung cancer (IARC 1990; ATSDR 2012; Hughes et al., 1994; Langård, 1990; Langård, 1993; Hayes, 1997; Davies, 1984; Ambroise et al., 2006; Sorensen et al., 2007), while others have also related chronic exposure to hexavalent chromium compounds to nasal and paranasal cancer. Satoh et al. (1994) reported four cases of carcinoma of the nasal region in male workers aged 19 to 32 years old employed in a Japanese chromate factory, and Comiati et al. (2017) described a case of a 64-year-old chrome plater who was diagnosed with sinonasal undifferentiated carcinoma after a latency period of 39 years working in the galvanic industry in the early 1970 s.

Figure $3 \mathrm{~A}$ and Figure 3B show a sinonasal cancer in a worker exposed to chromium and nickel compounds. Figure $3 \mathrm{~A}$ reproduces the initial computed tomography scan showing a lesion occupying the left maxillary sinus, which has destroyed the bone structure of the left maxilla and invaded the soft facial tissue and the pterygopalatine fossa. Figure $3 \mathrm{~B}$ reproduces the computed tomography scan 12 years later, after surgery and radiotherapy, showing changes in the nasal fossa and left maxillary sinus, with a fibrotic mass of scar tissue.

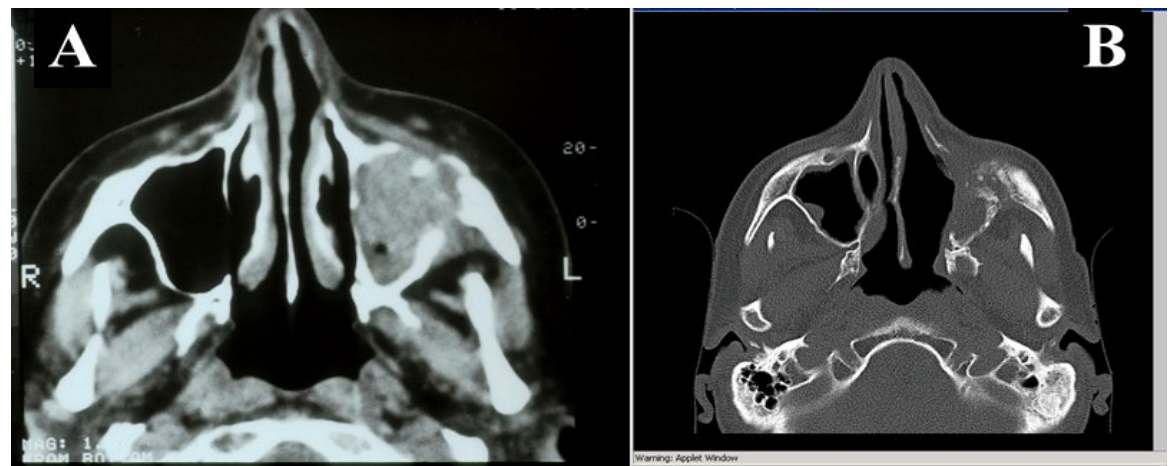

Figure 3A and 3B. Sinonasal cancer in a worker exposed to chromium and nickel compounds

Therefore, it is important to highlight the importance of studying occupational and nonoccupational exposure when assessing the concentration of substances in the urine.

This study describes a case of a worker exposed to lead chromate who has high concentrations of chromium in urine. 


\section{CASE STUDY}

To describe the case of a worker exposed to lead chromate who presented high chromium concentrations in urine, a study was conducted of the environmental chromium concentration in the workplace. This entailed a visit to the workplace to determine the characteristics of the reactors where the different pigments were obtained, including lead chromate (Figure 4).

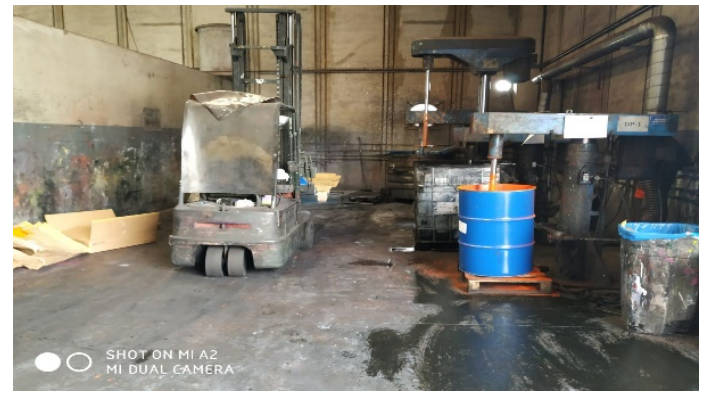

Figure 4. Mixing room where pigments for industrial use are manufactured

In addition, an occupational medical examination was performed, which included recording activities inside and outside the workplace, eating habits, blood lead and urine chromium at the beginning and end of the workday. Health monitoring was carried out following the recommendations of the Health Department of the Government of Catalonia for workers exposed to chromium and its compounds (Sanz-Gallen et al., 2004).

The two sections below describe the methods used to determine chromium in urine and environmental chromium in the workplace.

\subsection{Urine analysis method}

\section{Sampling conditions}

- Sample: urine.

- Sampling time: end of the working week (two aliquots: one before the shift started and the other after it ended).

- Sample container: 50-100 mL polypropylene bottle, previously acidified.

- Conditions for collecting the sample: an information sheet was sent to the worker indicating the correct conditions for collecting the sample.

- Minimum sample volume: $20 \mathrm{~mL}$.

- Storage prior to shipment: 0-1 hour: room temperature, 1-4 hours: refrigerated (5$\left.8^{\circ} \mathrm{C}\right)$ and $>4$ hours: frozen $\left(-20^{\circ} \mathrm{C}\right)$.

\section{Sample transportation}

Use of three-layer packaging (waterproof, waterproof and resistant) to achieve various levels of protection.

\section{Determination of urinary chromium concentration}

Chromium was determined by atomic absorption in an electrothermal chamber. Before analysing the sample, optimal measurement conditions were confirmed by carrying out internal quality-control tests and validating the results according to the procedure established in the laboratory. After confirming the reliability of the results obtained from the instrument, the chromium concentration was determined in each of the urine samples. 


\subsection{Air chromium analysis method}

Hexavalent chromium was determined using the NIOSH 7605 method (NIOSH, 2003). Technique: ion chromatography with post-column derivation and ultraviolet detection, using a PVC membrane filter. Sample collection time was 420 minutes. The limit of detection was $0.02 \mu \mathrm{g}$, and the limit of quantification was $0.07 \mu \mathrm{g}$. The working range was 0.25 to $100 \mu \mathrm{g} / \mathrm{m}^{3}$ for a $200 \mathrm{~L}$ air sample.

\section{RESULTS}

A 56-year-old man with no relevant medical history who was a non-smoker and a sporadic consumer of alcoholic beverages.

For 11 years, he had been working in a factory that manufactures pigments and additives for the chemical industry (paints, textiles, leather, ceramics, dyes, agrochemicals and others). Most of the components of these pigments are organic, but the factory also produces some inorganic pigments such as lead chromate. The worker spent 12 hours a week (six hours a day, two days a week) producing lead chromate.

An occupational medical examination detected a blood lead level of $6 \mu \mathrm{g} / \mathrm{dL}$ (Spanish biological limit value (BLV): $70 \mu \mathrm{g} / \mathrm{dL}$, Spanish National Institute for Health and Safety at Work, 2019) and a urine chromium level at the end of the working day of $52 \mu \mathrm{g} / \mathrm{L}$ (BLV at the end of working week: $25 \mu \mathrm{g} / \mathrm{L}$, Spanish National Institute for Health and Safety at Work, 2019); blood and urine creatinine were in the normal range. Due to the high chromium concentrations in urine, working conditions and personal protective equipment were investigated. The environmental chromium concentrations in the workplace were below $0.25 \mathrm{\mu g} / \mathrm{m}^{3}$ (environmental limit value in Spain for lead chromate: $12 \mu \mathrm{g} / \mathrm{m}^{3}$ ).

A new analysis of chromium in urine was performed before and after work to determine the increase during the working day, detecting levels of $62 \mu \mathrm{g} / \mathrm{L}$ before starting work and $6 \mu \mathrm{g} / \mathrm{L}$ after finishing work. The tests were repeated a week later, yielding results of $41 \mu \mathrm{g} / \mathrm{L}$ before and $37 \mu \mathrm{g} / \mathrm{L}$ after work.

In view of these results, a full study was conducted of the patient's habits outside work. He reported having bought a kilo of a medicinal herb infusion (Equisetum Arvense, also known as common horsetail, a medicinal herb primarily used for its diuretic properties) at a street market three weeks previously. Since then, he had consumed 300-500 $\mathrm{mL} /$ day of this infusion. The total chromium concentration in a prepared infusion was $12000 \mathrm{\mu g} / \mathrm{L}$, while the concentration of total chromium in hot water before adding the herb was $4 \mu \mathrm{g} / \mathrm{L}$ (in Spain, the reference value for chromium in drinking water is less than $50 \mu \mathrm{g} / \mathrm{L})$.

The worker stopped consuming Equisetum Arvense, and the urine chromium analysis was repeated before and after work; in both cases, the results were below $0.5 \mu \mathrm{g} / \mathrm{L}$.

\section{DISCUSSION}

The absorption of chromium depends on speciation (or chemical species), on the solubility of the compound in the biological medium considered and on the particle size of the compound and its valence: trivalent derivatives are, in general, more weakly absorbed than hexavalent derivatives.

These latter include chromium trioxide, chromates and dichromates, of varying solubility in water. Compounds such as chromium trioxide (CrO3) and alkali metal chromates (potassium, sodium and lithium chromate) are soluble, whereas the alkaline earth metal salts (calcium chromate, strontium chromate) are less soluble, and the chromates of lead and zinc are practically insoluble.

The threshold limit value-time weighted average (TLV-TWA) is mainly used to assess environmental exposure in workplaces. The TLV-TWAs of chromium and its compounds vary considerably according to the country in the European Union (Hartwig et al., 2017), but in Spain, they are as follows $\left(\mu \mathrm{g} / \mathrm{m}^{3}\right): 50$ ( $\mathrm{Cr}$ VI insoluble compounds), 10 (Cr VI 
soluble compounds), 1 (calcium chromate), 0.5 (strontium chromate) and 12 (lead chromate).

Several changes have been made in the United States in recent years (Balmer, 2018). In 2006, the Occupational Safety and Health Administration (OSHA) lowered the permissible exposure limit (PEL) for $\mathrm{Cr}$ (VI, soluble) to the current level of $5 \mu \mathrm{g} / \mathrm{m}^{3}$. In March 2018, the American Conference of Governmental Industrial Hygienists (ACGIH ${ }^{\circledR}$ ) adopted a significantly lower threshold limit value $\left(\mathrm{TLV}^{\circledR}\right)$ for $\mathrm{Cr}(\mathrm{VI}$, water-soluble) of $0.02 \mu \mathrm{g} / \mathrm{m}^{3}$ (previously $50 \mu \mathrm{g} / \mathrm{m}^{3}$ ).

Soluble chromium VI derivatives can enter the body through all routes, but in the workplace, the respiratory route is the most common, although it may also enter via the digestive system $(<10 \%)$ (lack of hygiene) and more weakly through the skin (about $4 \%$ ). Trivalent derivatives (sulphate and chromium chloride) are less well absorbed than hexavalent derivatives by the respiratory route, very poorly absorbed via the digestive tract and do not appear to be absorbed in all through intact skin. The half-lives of blood chromium are 7 hours, 1-4 days and 3-12 months.

Chromium VI, which easily crosses cell membranes, is rapidly reduced to chromium III in cells of all tissues; it shows a particular affinity for red cells, where it is reduced and retained throughout their lifetime in the form of chromium III (capacity to form stable compounds with macromolecules). Chromium III is linked to proteins and is mainly distributed in the liver, kidney and spleen.

Excretion is mainly urinary $(>80 \%)$, in the form of chromium III, and weakly faecal. Urinary elimination is triphasic (elimination half-lives: 4.5-7 hours, 15 to 30 days, 4 years). People with high exposure accumulate chromium during the week and throughout the year (Tossavainen et al., 1980; Scheepers et al., 2008; Persoons et al., 2014; Genovese et al., 2015).

To perform biological monitoring of exposed workers, urine chromium concentrations are determined at the end of the working week and before and after the working day in order to determine any increase in chromium during the working day. The maximum acceptable urine value is $25 \mu \mathrm{g} / \mathrm{L}$ (at the end of the workday) and the difference between before and after work should not exceed $10 \mu \mathrm{g} / \mathrm{L}$ (Spanish National Institute for Health and Safety at Work, 2019).

It is important to note that biomonitoring values for hexavalent chromium are different according to country. Table 1 shows the urine chromium values in several European countries.

Table 1. Hexavalent chromium biomonitoring values according to country (adapted from Hartwig et al., 2017)

\begin{tabular}{lll}
\hline Term & Biomonitoring Values & Country \\
\hline $\mathrm{BLV}^{\mathrm{a}}$ & End of week $2.5 \mu \mathrm{g} / \mathrm{L}$ & France \\
\hline $\mathrm{VBR}^{\mathrm{b}}$ & $0.65 \mu \mathrm{g} / \mathrm{L}$ & France \\
\hline $\mathrm{BAR}^{\mathrm{c}}$ & $0.6 \mu \mathrm{gL}($ total chromium) & Germany \\
\hline $\mathrm{BMGV}^{\mathrm{d}}$ & $10 \mu \mathrm{mol} / \mathrm{mol}$ creatinine in urine (post-shift) & UK \\
\hline $\mathrm{BAT}^{\mathrm{e}}$ & $11 \mu \mathrm{g} / \mathrm{L}$ & Switzerland \\
\hline $\mathrm{BLV}^{\mathrm{a}}$ & Total chromium increase in urine during one shift & \\
& $10 \mu \mathrm{g} / \mathrm{L} ;$ at the end of the working week $25 \mu \mathrm{g} / \mathrm{L}$ & Spain
\end{tabular}

${ }^{a} B L V$, biological limit value; bVBR, valeur biologique de reference [biological reference value]; 'BAR, Biologischer-Arbeitsstoff Referenzwert [biological reference value]; dBAT, Biologische Arbeitsstofftoleranzwerte [biological occupational chemical tolerance level]; ${ }^{e} \mathrm{BMGV}$, biological monitoring guidance value.

Interpretation of the results obtained requires assessing the possible influences of tobacco, age, consumption of foods rich in $\mathrm{Cr}$ III, personal hygiene and skin status (ATSDR, 2012). It is also necessary to assess chromium release from altered metal 
prostheses (chromium-based alloy materials) and osteosynthesis materials that may raise concentrations of urine chromium well above reference values for the general population (Aras et al., 2013).

In our case, the worker exhibited high concentrations of chromium in urine. As these concentrations were high before the working day, an investigation was conducted and high consumption of Equisetum Arvense was detected. The chromium concentrations in the infusion were analysed and found to be very high. The worker ceased consumption, and in the subsequent analysis, urine chromium concentrations were within the normal limits and consistent with environmental concentrations in the workplace.

The consumption of infusions as common as tea (Camellia Sinenses $L$ ) can increase chromium concentrations in biological liquids. Barman et al. (2019) have conducted extensive research on the detection of arsenic and chromium in this type of plant, finding that the concentration of chromium in some tested black tea samples varied from 0.62 to $36.76 \mu \mathrm{g} / \mathrm{g}$, with a mean and median of $10.33 \mu \mathrm{g} \mathrm{g}-1$ and $8.33 \mu \mathrm{g} \mathrm{g}-1$, respectively (Barman et al., 2019).

Our case is interesting because it demonstrates that the consumption of medicinal herbs can interfere with biological monitoring carried out in workers exposed to hexavalent chromium compounds. This may give rise to confusion and can also create legal problems for companies and workers.

\section{CONCLUSIONS}

It is important to provide advice to workers and to investigate their habits outside work, especially when there is a discrepancy between environmental and biological values. It is also important to stress the risks of buying medicinal plants in street markets since there is no quality control of the products on sale there.

\section{REFERENCES}

Agència Catalana de Seguretat Alimentària. (ACSA). (2017). Element traça en els aliments. Estudi de dieta total a Catalunya. Generalitat de Catalunya. Departament de Salut. Barcelona. http://acsa.gencat.cat/ca/eines_i_recursos/publicacions/estudis_de_dieta_total/elements_traca _en_els_aliments._estudi_de_dieta_total/

Ambroise D, Wild P, Moulin J]. (2006). Update of a meta-analysis on lung cancer and welding. Scand J Environ Health, 32, 22-31. https://doi.org/10.5271/sjweh.973

Aras M, Parlanti C, Glaizal M, Tichadou L et al (2013). - Imprégnation par le chrome liée au matériel d'ostéosynthèse. A propos d'une observation. Ann Toxicol Anal, 25 (1) , 33-36. https://doi.org/10.1051/ata/2013026

Agency for Toxic Substances and Disease Registry (ATSDR) (2012). Toxicological profile for chromium. Atlanta, GA: US Department of Health and Human Services, Public Health Service, Agency for Toxic Substances and Disease Registry. http://atsdr.cdc.gov/toxprofiles/tp7.pdf

Balmer, J. (2018). Hexavalent Chromium. Workplace Health \& Safety, 66(11), 564-564. https://doi.org/10.1177/2165079918805775

Donald G. Barceloux \& Dr. Donald Barceloux (1999) Chromium, Journal of Toxicology: Clinical Toxicology, 37:2, 173-194, DOI: 10.1081/CLT-100102418

Barman T, Barooak AK, Goswani BC, Sharma N, Panja S, Khare P, Karak T. (2019). Contents of Chromium and Arsenic in Tea (Camellia sinensis L.): Extent of Transfer into Tea Infusion and Health Consequence. Biol Trace Elem Res. https://doi.org/10.1007/s12011-019-01889-y

Centres for Disease Control and Prevention. NIOSH. (2013). Criteria for a Recommended Standard. Occupational Exposure to Hexavalent Chromium. USA. www.cdc.gov/niosh/docs/2013128/default.htlm

Comiati V, Scapellato ML, Alexandre E, Volo T, Borsetto D, Carrieri M, Emanuelli E, Cazzador D. (2017). Sinonasal cancer in a worker exposed to chromium in an unusual industrial sector. Med Lav, 108, 477-481. https://doi.org/10.23749/mdl.v108i6.6606

Davies JM.(1984). Lung cancer mortality among workers making lead chromate and zinc chromate pigments at three English factories. $\mathrm{Br} \mathrm{J}$ Ind Med, 41, 158-164. https://doi.org/10.1136/oem.41.2.158 
European Food Safety Authority. (EFSA). (2014). Panel on Dietetic Products, Nutrition and Allergies. Scientific Opinion on dietary reference values for chromium. EFSA Journal, 12(10):3845 [25 p.]. Disponible a: https://www.efsa.europa.eu/en/efsajournal/pub/3845.

Genovese G, Castiglia L, Pieri M, et al. (2015) Occupational exposure to chromium of assembly workers in aviation industries. J Occup Environ Hyg, 12 , 518-24. https://doi.org/10.1080/15459624.2015.1019075

Gibb HJ, Lees PSJ, Pinsky PF, Rooney BC (2000) Lung cancer among workers in chromium chemical production. Am J Ind Med, 38, 115-126. 0274(200008)38:2<115::AID-AJIM1>3.0.CO;2-Y

Handley J, Burrows D [1994]. Dermatitis from hexavalent chromate in the accelerator of an epoxy sealant (PR1422) used in the aircraft industry. Contact Dermatitis 30, 193-196. https://doi.org/10.1111/j.1600-0536.1994.tb02020.x

Hartwig A, Heederik D, Kromhout H, Levy L, Papameletion D, Klein CL. (2017). SCOEL/Rec/386. Chromium VI compounds. European Commission. Brussels. https://doi.org/10.2767/14195

Hayes RB [1997]. The carcinogenicity of metals in humans. Cancer Causes Control 8(3):371-385. https://doi.org/10.1023/a:1018457305212

Hughes K, Meek ME, Seed LJ, Shedden J (1994). Chromium and its compounds: evaluation of risks to health from environmental exposure in Canada. J Environ Sci Health Part C Environ Carcino \& Ecotox Revs 12(2):237-255. https://doi.org/10.1080/10590509409373443

International Agency for Research on Cancer (IARC). (1990) IARC monographs on the evaluation of the carcinogenic risk of chemicals to man: chromium, nickel, and welding. Vol. 49. Lyon, France: World Health Organization, International Agency for Research on Cancer, pp. 49-256.

Instituto Nacional de la Seguridad y Salud en el Trabajo (INSST) (2019). Límites de Exposición Profesional para Agentes Químicos en España, Ministerio de Trabajo, Migraciones y Seguridad Social, Madrid

Langård S (1990). One hundred years of chromium and cancer: a review of epidemiological evidence and selected case reports. Am J Ind Med 17(2):189-215. https://doi.org/10.1002/ajim.4700170205

Langård S (1993). Role of chemical species and exposure characteristics in cancer among persons occupationally exposed to chromium compounds. Scand J Work Environ Health 19(Suppl 1):8189. PMID: 8159981

Lee CR, Yoo CI, Lee J, Kang SK [2002]. Nasal septum perforation of welders. Ind Health 40(3):286289. https://doi.org/10.2486/indhealth.40.286

Loubières Y, de Lassence A, Bernier M, Vieillard-Baron A, Schmitt J-M, Page B \& Jardin F. (1999). Acute, Fatal, Oral Chromic Acid Poisoning, Journal of Toxicology: Clinical Toxicology, 37, 333-336. https://doi.org/10.1081/CLT-100102431

Mertz W (1993). Chromium in human nutrition: a review. J Nutr,123,62633. https://doi.org/10.1093/jn/123.4.626

National Institute for Occupational Safety and Health (NIOSH). (2003). Manual of Analytical Methods (NMAM) Fourth Edition. Chromium, Hexavalent: Method 7605, Issue 1 dated 15 March 2003. www.cdc.gov/niosh/docs/2003-154/pdfs/7605.pdf

Occupational Exposure to Hexavalent Chromium. Federal Register: February 28, 2006 (Volume 71, Number 39: 10099-10385. https://www.osha.gov/laws-regs/federalregister/2006-02-28-0

Persoons R, Arnoux D, Monssu T, Culié O et al.(2014). Determinants of occupational exposure to metals by gas metal arc welding and risk management measures: A biomonitoring study. Toxicol Lett,231,135-41. https://doi.org/10.1016/j.toxlet.2014.09.008

Sanz P, Moliné JL, Solé D, Corbella J. (1989). Nasal septum perforation in chromate-producing industry in Spain. J Occup Med, 31,1013-1014. https://doi.org/10.1097/00043764-198912000-00016

Sanz P, Nogué S, Munné P, Torra R, Marqués F. (1991). Acute Potassium Dichromate Poisoning. Hum Exp Toxicol. 10, 228-229. https://doi.org/10.1177/096032719101000315

Sanz-Gallen P, Badosa Gomà R, Molina Aragonés JMa, Rull Valdivia G, Veciana Gramunt L (2004). Agents quimics. Crom i compostos. Guíes de bona praxi. Vigilància de la Salut. Departament de Salut. Generalitat de Catalunya. Barcelona.2004. www.canalsalut.gencat.cat/web/.content/_AZ/S/salut_laboral/11_salut_laboral/arxius/crom.pdf 
Sanz-Gallen P, Pérez-Nicolás J, Cobo E, Solé D, Marqués F, Moreno N, Corbella J (1988). Lung function in the workers of a cromate producing industry. G Ital Med Lav, 10, 235-237. PMID: 3154904

Sanz-Gallen P., Pérez-Nicolás J, Solé D., \& Corbella J. (1990). Conséquences tardives de l'exposition au chrome: étude d'une population de salariés après exposition au risque. Archives des maladies professionnelles de médecine du travail et de sécurité sociale, 51, 587-588.

Santonen T, Alimonti A, Bocca B, et al (2019). Setting up a collaborative European human biological monitoring study on occupational exposure to hexavalent chromium. Enviromental Research 177 (108583), 1-11. https://doi.org/10.1016/j.envres.2019.108583

-Scheepers PT, Heussen GA, Peer PG, Verbist K, Anzion R, Willems J. (2008) .Characterisation of exposure to total and hexavalent chromium of welders using biological monitoring. Toxicol Lett. 178 (3), 185-90. https://doi.org/10.1016/j.toxlet.2008.03.013

Satoh N, Fukuda S, Takizawa M, Furuta Y, Kashiwamura M, Inuyama Y [1994]. Chromium-induced carcinoma in the nasal region. A report of four cases. Rhinology 32(1):47-50. PMID: 8029624

Sørensen AR, Thulstrup AM, Hansen J, Ramlau-Hansen CH, Meersohn A, Skytthe A, Bonde JP. (2007). Risk of lung cancer according to mild steel and stainless-steel welding. Scand J Work Environ Health, 33,379-386. https://doi.org/10.5271/sjweh.1157

Tossavainen A, Norminen M, Mutanen P, Tola S. (1980). Application of mathematical modeling for assessing the biological half-times of chromium and nickel in field studies. $\mathrm{Br} \mathrm{J}$ Ind Med, 37, 285291. https://doi.org/10.1136/oem.37.3.285 